\title{
Characterization of the chloramphenicol acetyltransferase variants encoded by the plasmids pSCS6 and pSCS7 from Staphylococcus aureus
}

\author{
Marisa Cardoso and Stefan Schwarz* \\ Institut für Bakteriologie und Immunologie der Justus Liebig Universität Gießen, Frankfurterstr. 107, 6300 Gießen, FRG
}

(Received 2 September 1991; revised 13 October 1991; accepted 23 October 1991)

\begin{abstract}
The two $4.6 \mathrm{~kb}$ chloramphenicol resistance $\left(\mathrm{Cm}^{\mathrm{R}}\right)$ plasmids pSCS6 and pSCS7, previously identified in Staphylococcus aureus from subclinical bovine mastitis, both encoded an inducible chloramphenicol acetyltransferase (CAT, EC 2.3.1.28). The pSCS6- and pSCS7-encoded CAT variants were purified by ammonium sulphate precipitation, ion-exchange chromatography and fast protein liquid chromatography (FPLC). Both native enzymes showed $M_{\mathrm{r}}$ values of 70000 on FPLC and were composed of three identical subunits, each of $M_{\mathrm{r}}$ approximately 23000. The CAT variants from pSCS6 and pSCS7 differed in their net charges and in their isoelectric points. The isoelectric point of the CAT from pSCS6 was pH 5.7 and that of the CAT from pSCS7 pH 5.2. Both CAT variants exhibited highest enzyme activities at $\mathrm{pH} \mathrm{8.0.} \mathrm{The} K_{\mathrm{m}}$ values for chloramphenicol and acetyl-CoA of the CAT from pSCS6 were $2.5 \mu \mathrm{M}$ and $58.8 \mu \mathrm{M}$, respectively, while those of the CAT from pSCS7 were $2.7 \mu \mathrm{M}$ and $55.5 \mu \mathrm{M}$. Both CAT variants were relatively thermostable. The CAT from pSCS6 was less sensitive to mercuric ions than the CAT from pSCS7.
\end{abstract}

\section{Introduction}

Staphylococcus aureus is one of the major bacterial pathogens associated with bovine mastitis (Baumgartner et al., 1984). Antibiotics are often used to control $S$. aureus infections (Blobel \& Brückler, 1980), and this has led to $S$. aureus isolates becoming increasingly resistant to antimicrobial agents. In $S$. aureus isolates from infections of humans, several antibiotic-resistance genes have been found to be located on plasmids (Lacey, 1975; Lyon \& Skurray, 1987). Chloramphenicol resistance $\left(\mathrm{Cm}^{\mathrm{R}}\right)$ is exclusively encoded by small non-conjugative plasmids (Lyon \& Skurray, 1987). Several $\mathrm{Cm}^{\mathrm{R}}$ plasmids have been isolated from $S$. aureus of human origin and their structure and properties investigated (Gillespie \& Skurray, 1988).

Although the existence of plasmids in $S$. aureus of bovine origin has been demonstrated before, their role in antibiotic resistance remains to be determined (Baumgartner et al., 1984). Recently, four small $\mathrm{Cm}^{\mathrm{R}}$ plasmids were isolated from bovine $S$. aureus (Cardoso \& Schwarz, 1992a). The chloramphenicol acetyltransferase (cat)

* Author for correspondence. Tel. 0641702 4835; fax 06417027390.

Abbreviations: CAT, chloramphenicol acetyltransferase. genes of two of these plasmids, pSCS6 and pSCS7, have been sequenced, and differences were noted both in their nucleotide sequences and in their predicted CAT amino acid sequences (Schwarz \& Cardoso, $1991 b$; Cardoso \& Schwarz, 1992b).

The purpose of this investigation was to determine whether the differences in the nucleotide sequences of the pSCS6- and pSCS7-encoded cat genes could be associated with differences in the biochemical properties of the respective gene products. The CATs were purified and their subunit composition, their isoelectric points, their $\mathrm{pH}$ optima, their $K_{\mathrm{m}}$ values for chloramphenicol and acetyl-CoA, their thermostability and their sensitivity to mercuric ions were compared.

\section{Methods}

Bacterial strains, plasmids and growth conditions. The $\mathrm{Cm}^{\mathrm{R}}$ plasmids pSCS6 and pSCS7 had previously been transferred into $S$. aureus RN4220 (Kreiswirth et al., 1983; Cardoso \& Schwarz, 1992a). These transformants were used to isolate the pSCS6- and pSCS7-encoded CAT variants. Single colonies from the stock culture plates were grown in Brain Heart Infusion broth (BHI, Gibco) for $18 \mathrm{~h}$ at $37^{\circ} \mathrm{C}$ on a rotary shaker (160 r.p.m.).

Enzymic inactivation of chloramphenicol by acetylation. A previously described bioassay was used to demonstrate enzymic inactivation of 
chloramphenicol (Schwarz et al., 1989). Chloramphenicol acetyltransferases (CATs) were responsible for $\mathrm{Cm}^{\mathrm{R}}$ as revealed by the rapid CAT assay (Shaw, 1975).

Isolation of CAT. (a) Induction of CAT. Expression of staphylococcal CAT variants is inducible (Lyon \& Skurray, 1987). Induction of CAT is achieved with chloramphenicol (Winshell \& Shaw, 1969), but since chloramphenicol is itself a substrate for CAT, the inducer is rapidly inactivated, leading to reduced induction rates. In order to optimize CAT induction, acetylated chloramphenicol had to be replaced by fresh chloramphenicol after each doubling of the RN4220(pSCS6) and RN4220(pSCS7) cultures to a final concentration of $50 \mu \mathrm{g} \mathrm{ml}^{-1}$. The transformants were grown in $50 \mathrm{ml} \mathrm{BHI}$ to an $\mathrm{OD}_{600}$ of 0.65 . After a final addition of chloramphenicol, the cultures were grown for a further $30 \mathrm{~min}$ at $37^{\circ} \mathrm{C}$. The cells were then harvested by centrifugation $\left(20 \mathrm{~min}, 4^{\circ} \mathrm{C}, 6000 \mathrm{~g}\right)$.

To confirm the inducibility of the pSCS6- and pSCS7-encoded CAT variants, cultures were grown in the same manner, except that the medium was not supplemented with chloramphenicol.

(b) Cell-free lysates and SDS-PAGE. The harvested cells were washed with $5 \mathrm{ml} \mathrm{TS}$ buffer ( $50 \mathrm{~mm}-\mathrm{Tris} / \mathrm{HCl}$ and $145 \mathrm{~mm}-\mathrm{NaCl}, \mathrm{pH} 7.5$ ). After resuspending the bacteria in $1 \mathrm{ml}$ of the same buffer, lysostaphin $\left(80 \mu \mathrm{g} \mathrm{ml}^{-1}\right)$ was added. After $15 \mathrm{~min}$ at $37^{\circ} \mathrm{C}$, DNAase $\left(20 \mu \mathrm{g} \mathrm{ml}^{-1}\right)$ was added, followed by $15 \mathrm{~min}$ incubation at $37^{\circ} \mathrm{C}$. The supernatant obtained after centrifugation $\left(20 \mathrm{~min}, 4^{\circ} \mathrm{C}, 15000 \mathrm{~g}\right.$ ) was analysed by SDS-PAGE using $11 \%(\mathrm{w} / \mathrm{v})$ polyacrylamide gels (Maniatis et al., 1982) at $10 \mathrm{~V} \mathrm{~cm}^{-1}$ for $6 \mathrm{~h}$ (Laemmli, 1970).

(c) Purification of CAT. Lysates of cells harvested from 5 litres of chloramphenicol-induced RN4220(pSCS6) and RN4220(pSCS7) cultures were prepared. CAT was precipitated by the addition of ammonium sulphate to $70 \%$ saturation, followed by stirring at $4{ }^{\circ} \mathrm{C}$ for $12 \mathrm{~h}$. The precipitate was collected by centrifugation $\left(30 \mathrm{~min}, 4^{\circ} \mathrm{C}\right.$, $15000 \mathrm{~g}$ ), resuspended in $20 \mathrm{ml} \mathrm{TCM}$ buffer $(50 \mathrm{mM}-\mathrm{Tris} / \mathrm{HCl} \mathrm{pH} \mathrm{7.8,}$ $50 \mathrm{~mm}$-mercaptoethanol, $0.2 \mathrm{~mm}$-chloramphenicol) and dialysed against the same buffer for $18 \mathrm{~h}$. Then the CAT-containing solution was applied to a DEAE-cellulose column $(3 \times 10 \mathrm{~cm}, \mathrm{DE}-52$, Whatman) equilibrated with TCM buffer. The column was washed with TCM buffer and CAT was eluted with a linear gradient of 0 to $0.4 \mathrm{M}-\mathrm{NaCl}$ at a flow rate of $40 \mathrm{ml} \mathrm{h}^{-1}$. Fractions of $5 \mathrm{ml}$ were collected and tested for CAT activity using the rapid CAT assay (Shaw, 1975).

The ion-exchange chromatography fraction with the highest CAT activity was applied in $200 \mu$ samples to a Superose FPLC column (12 HR, 10/30, LKB) which had been equilibrated with $50 \mathrm{~mm}$-sodium phosphate buffer ( $\mathrm{pH} 7 \cdot 3$ ) supplemented with $100 \mathrm{~mm}-\mathrm{NaCl}$. Elution profiles and times were monitored with a Knaur UV/VIS filter photometer and a Shimadzu C-R3A chromatopac processor. The fractions of the respective protein peaks were collected and tested for CAT activity. A $20 \mu \mathrm{l}$ sample of the FPLC fraction with the highest CAT activity was finally analysed by $15 \%(w / v)$ SDS-PAGE.

Electrophoresis of the native CAT variants was carried out in $1 \%$ (w/v) agarose gels in $65 \mathrm{~mm}$-sodium barbital buffer (Shaw et al., 1970). Agarose gels were run at running-buffer $\mathrm{pH}$ values of $5 \cdot 5,6 \cdot 0,6 \cdot 5,7 \cdot 0$, 7.5 and 8.0 for $2 \mathrm{~h}$ at $12 \mathrm{~V} \mathrm{~cm}^{-1}$. Proteins were detected by staining with Coomassie Brilliant Blue.

Protein determinations. Protein was precipitated by the addition of an equal volume of $20 \%(\mathrm{w} / \mathrm{v})$ trichloroacetic acid (TCA). After $16 \mathrm{~h}$ at $4{ }^{\circ} \mathrm{C}$ the precipitates were centrifuged and washed twice with $10 \%$ (w/v) TCA. The protein content was measured by the Lowry method, with bovine serum albumin (Serva) as a standard.

$M_{\mathrm{r}}$ determination of native $C A T$. The $M_{\mathrm{r}}$ of native CAT was determined by FPLC with a Superose column (12 HR, 10/30, LKB) at a flow rate of $30 \mathrm{ml} \mathrm{h}^{-1}$ and an elution buffer consisting of $50 \mathrm{mM}$-sodium phosphate (pH 7.3) and $50 \mathrm{~mm}-\mathrm{NaCl}$. A calibration curve was constructed with the following proteins, obtained from Serva: RNAase
A $\left(M_{\mathrm{r}} 13700\right)$, ovalbumin (45000), bovine serum albumin $(67000)$ and aldolase (160000).

Isoelectric focussing. The ion-exchange chromatography fraction with the highest CAT activity was dialysed against distilled water for $24 \mathrm{~h}$ and then applied to a preparative isoelectric focussing column (110 ml, LKB) under the conditions described by Schaeg et al. (1972). The carrier ampholytes ranged from $\mathrm{pH} 3.5$ to $10 \cdot 0$. Fractions of $1 \mathrm{ml}$ were collected and investigated for $\mathrm{pH}$ and CAT activity as previously described (Schwarz \& Cardoso, 1991a).

Enzyme kinetics. The Michaelis constants were determined using spectrophotometric enzyme assays under saturating second-substrate conditions (100 $\mu \mathrm{M}$-chloramphenicol or $200 \mu \mathrm{M}$-acetyl-CoA) (Fitton \& Shaw, 1979). For these assays, the FPLC-purified CAT solution $\left(1 \mathrm{U} \mathrm{ml}^{-1}\right.$ in $50 \mathrm{~mm}$-Tris/HCl $\mathrm{pH} \mathrm{7.8)}$ was diluted 1000 -fold. Firstsubstrate concentrations of $1.0,1.5,2.0,2.5$ and $3.0 \mu \mathrm{M}$-chloramphenicol, and 10, 20, 30, 40, 50,60 and $70 \mu \mathrm{M}$-acetyl-CoA, were used. Double reciprocal plots of velocity versus first-substrate concentrations according to Lineweaver \& Burk (1934) were prepared. The velocity of the enzyme reaction was expressed as production of CAT-dependent 5-thio-2-nitrobenzoate after $1 \mathrm{~min}$ and $3 \mathrm{~min}$ at $37^{\circ} \mathrm{C}$. The assays were linear over the entire $3 \mathrm{~min}$ period. All measurements were performed in triplicate for each concentration of substrate. The method of least squares was used to find the slope of the straight line.

Influence of $p H$ on CAT activity. The effect of $\mathrm{pH}$ on the activity of the pSCS6- and pSCS7-encoded CAT variants was determined spectrophotometrically, assaying $10 \mu \mathrm{l}$ samples of a DEAE-cellulose-purified CAT solution $\left(3 \mathrm{U} \mathrm{ml}^{-1}\right)$ at $\mathrm{pH}$ values of $6 \cdot 0,6 \cdot 5,7 \cdot 0,7 \cdot 5,7 \cdot 8,8 \cdot 0$ and $8 \cdot 5$.

Influence of temperature on CAT activity. Samples $(100 \mu \mathrm{l})$ of the FPLC-purified CAT solution $\left(1 \mathrm{U} \mathrm{ml}^{-1}\right)$ were heated at $70^{\circ} \mathrm{C}$ in a water bath for $1,3,6,9,12$ and $15 \mathrm{~min}$ and subsequently tested for their CAT activity. A $100 \mu 1$ sample of the same CAT solution, but not heattreated, served as a control for the original CAT activity.

Influence of mercuric ions on CAT activity. The DEAE-cellulosepurified CAT solution $\left(3 \mathrm{U} \mathrm{ml}^{-1}\right)$ was dialysed overnight at $4{ }^{\circ} \mathrm{C}$ against $50 \mathrm{~mm}-\mathrm{Tris} / \mathrm{HCl}(\mathrm{pH} 7.8)$ to eliminate residual chloramphenicol, which protects CAT against mercuric ions. Samples $(500 \mu \mathrm{l})$ were supplemented with $\mathrm{HgCl}_{2}$ to $0 \cdot 1,0 \cdot 3,0.5$ and $1.0 \mathrm{~mm}$ and subsequently incubated for $10 \mathrm{~min}$ at $37^{\circ} \mathrm{C}$. Since mercury ions might interfere with the CAT assay, the samples were then dialysed again overnight at $4{ }^{\circ} \mathrm{C}$ against $50 \mathrm{~mm}-\mathrm{Tris} / \mathrm{HCl}(\mathrm{pH} 7.8)$. CAT activity was finally determined by the rapid CAT assay. The same CAT solution, also dialysed twice but not supplemented with $\mathrm{HgCl}_{2}$, was used to determine the original CAT activity.

\section{Results}

\section{Mechanism of chloramphenicol resistance}

Enzymic inactivation of chloramphenicol by the RN4220(pSCS6) and RN4220(pSCS7) transformants was demonstrated by bioassay. The enzymes were shown to inactivate chloramphenicol by acetylation in the presence of acetyl-CoA by the rapid CAT assay. Monomers of the pSCS6- and pSCS7-encoded CAT variants were detectable in SDS-PAGE of lysates of chloramphenicol-induced cells, but not in those of 




Fig. 1. SDS-PAGE of cell-free lysates of chloramphenicol-induced (lanes 1) and uninduced (lanes 2) pSCS6 $(a)$ and pSCS7 $(b)$ transformants. Lanes $M$ contain protein markers. The CAT monomers are indicated by arrowheads. uninduced cells (Fig. 1). Thus, both CAT variants were considered to be inducible.

\section{Purification of CAT}

The pSCS6- and pSCS7-encoded CAT variants were purified by ammonium sulphate precipitation followed by ion-exchange chromatography. The CATs differed in their elution profiles on ion-exchange chromatography: while the CAT from pSCS6 could be eluted at $52 \mathrm{~mm}-$ $\mathrm{NaCl}$, the CAT from pSCS7 was eluted at $74 \mathrm{~mm}-\mathrm{NaCl}$. FPLC allowed purification to homogeneity as indicated by SDS-PAGE analysis, which revealed single bands of $M_{\text {r }} 23000$ (Fig. 2).

Table 1 shows the results of the purification procedures. The purified CAT variants differed slightly in their specific activities: $280 \mathrm{U}$ (mg protein $)^{-1}$ for the CAT from pSCS6, and $240 \mathrm{U}$ (mg protein) ${ }^{-1}$ for the CAT from pSCS7.

\section{$M_{\mathrm{r}}$ and subunit structure}

The $M_{\mathrm{r}}$ values of the native CAT variants were determined by FPLC to be approximately 70000 in each case (results not shown). On SDS-PAGE, both enzymes appeared as a single band of $M_{\mathrm{r}} 23000$ (Fig. 2). Thus, the pSCS6- and pSCS7-encoded CAT variants appeared to be trimers composed of three identical subunits, each with an $M_{\mathrm{r}}$ of 23000 .

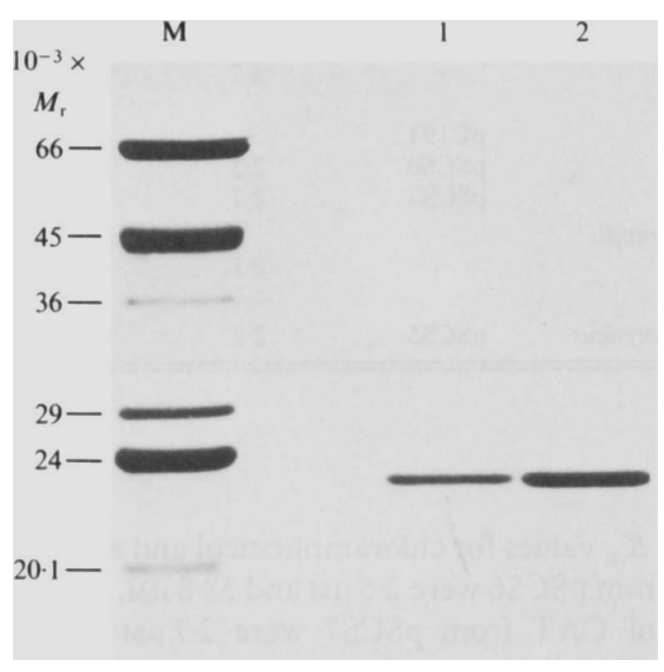

Fig. 2. SDS-PAGE of the FPLC-purified CAT variants from pSCS6 (lane 1) and pSCS7 (lane 2). Lane $M$ contains protein markers.

\section{Isoelectric point and enzyme kinetics}

The purified CATs differed in their isoelectric points. These were $\mathrm{pH} 5.7$ for the CAT from pSCS6 and pH 5.2 for the CAT from pSCS7 (Table 2). Moreover, agarose gel electrophoresis of the non-denatured proteins demonstrated differences in the net charge. The CATs differed in their anodal migration patterns at varying $\mathrm{pH}$ values with respect to their isoelectric points (Fig. 3). 
Table 1. Purification of the CAT variants encoded by the plasmids pSCS6 and pSCS7 from

\section{$S$. aureus}

\begin{tabular}{|c|c|c|c|c|c|}
\hline $\begin{array}{l}\text { CAT } \\
\text { encoded } \\
\text { by }\end{array}$ & $\begin{array}{l}\text { Purification } \\
\text { step }\end{array}$ & $\begin{array}{c}\text { Total } \\
\text { ativity } \\
\text { (units } \mathbf{~ m l}^{-1} \text { ) }\end{array}$ & $\begin{array}{c}\text { Total } \\
\text { protein } \\
\left(\mathrm{mg} \mathrm{ml}^{-1}\right)\end{array}$ & $\begin{array}{c}\text { Specific } \\
\text { activity } \\
{[\text { units }} \\
\left.\text { (mg protein })^{-1}\right]\end{array}$ & $\begin{array}{l}\text { Purification } \\
\text { factor }\end{array}$ \\
\hline \multirow[t]{2}{*}{ pSCS6 } & $\begin{array}{l}\text { Cell-free lysate } \\
\text { lon-exchange }\end{array}$ & $2 \cdot 5$ & 3.600 & 0.7 & 1.0 \\
\hline & $\begin{array}{l}\text { chromatography } \\
\text { FPLC }\end{array}$ & $\begin{array}{r}16 \cdot 2 \\
7.0\end{array}$ & $\begin{array}{l}1.760 \\
0.025\end{array}$ & $\begin{array}{r}9 \cdot 2 \\
280 \cdot 0\end{array}$ & $\begin{array}{r}13 \cdot 1 \\
400 \cdot 0\end{array}$ \\
\hline \multirow[t]{3}{*}{$\mathrm{pSCS} 7$} & $\begin{array}{l}\text { Cell-free lysate } \\
\text { Ion-exchange }\end{array}$ & $2 \cdot 5$ & $2 \cdot 700$ & 0.9 & $1 \cdot 0$ \\
\hline & chromatography & $11 \cdot 0$ & $1 \cdot 170$ & 9.4 & $10 \cdot 4$ \\
\hline & FPLC & 6.0 & 0.025 & $240 \cdot 0$ & $266 \cdot 7$ \\
\hline
\end{tabular}

Table 2. Properties of staphylococcal CAT variants

\begin{tabular}{|c|c|c|c|c|c|c|c|}
\hline \multirow{2}{*}{$\begin{array}{l}\text { Staphylococcal } \\
\text { species and } \\
\text { enzyme type }\end{array}$} & \multirow[b]{2}{*}{ Plasmid } & \multicolumn{2}{|c|}{$K_{\mathrm{m}}(\mu \mathrm{M})$} & \multirow[b]{2}{*}{$\begin{array}{l}\text { Isoelectric } \\
\text { point }\end{array}$} & \multirow[b]{2}{*}{$\begin{array}{c}\mathrm{pH} \\
\text { optimum }\end{array}$} & \multirow[b]{2}{*}{$\begin{array}{c}\text { Heat } \\
\text { stability }\end{array}$} & \multirow[b]{2}{*}{ Reference(s) } \\
\hline & & $\begin{array}{l}\text { Chloram- } \\
\text { phenicol }\end{array}$ & $\begin{array}{c}\text { Acetyl- } \\
\mathrm{CoA}\end{array}$ & & & & \\
\hline \multicolumn{8}{|l|}{ S. aureus } \\
\hline A & - & $2 \cdot 6$ & 57 & - & - & Unstable & $\begin{array}{l}\text { Fitton \& Shaw (1979) } \\
\text { Shaw (1975) }\end{array}$ \\
\hline $\mathrm{C}$ & $\mathrm{pC} 221$ & $2 \cdot 5$ & 61 & - & $8 \cdot 0$ & Stable & $\begin{array}{l}\text { Fitton \& Shaw (1979) } \\
\text { Shaw et al. (1970) }\end{array}$ \\
\hline D & - & $2 \cdot 7$ & 47 & - & - & Stable & $\begin{array}{l}\text { Fitton \& Shaw (1979) } \\
\text { Shaw (1975) }\end{array}$ \\
\hline- & $\mathrm{pC} 194$ & - & - & - & - & - & Shaw (1983) \\
\hline- & pSCS6 & $2 \cdot 5$ & 59 & $5 \cdot 70$ & $8 \cdot 0$ & Stable & This paper \\
\hline - & pSCS7 & $2 \cdot 7$ & 56 & $5 \cdot 20$ & $8 \cdot 0$ & Stable & This paper \\
\hline \multicolumn{8}{|l|}{ S. epidermidis } \\
\hline B & - & $2 \cdot 7$ & 56 & - & $8 \cdot 0$ & Stable & $\begin{array}{l}\text { Shaw et al. (1970) } \\
\text { Shaw (1975) }\end{array}$ \\
\hline S. haemolyticus & pSCS5 & $2 \cdot 8$ & 52 & $6 \cdot 15$ & $7 \cdot 8$ & Stable & Schwarz \& Cardoso (1991a) \\
\hline
\end{tabular}

- , No data available.

The $K_{\mathrm{m}}$ values for chloramphenicol and acetyl-CoA of CAT from pSCS6 were $2.5 \mu \mathrm{M}$ and $58.8 \mu \mathrm{M}$, respectively; those of CAT from pSCS7 were $2.7 \mu \mathrm{M}$ and $55.5 \mu \mathrm{M}$ (Table 2).

Effects of $p H$, temperature and mercuric ions on $C A T$ activity

Both CAT variants demonstrated highest activity at pH 8.0 (Table 2). They also proved to be relatively thermostable since the CAT activities remaining after $15 \mathrm{~min}$ at $70{ }^{\circ} \mathrm{C}$ were approximately $60 \%$ (pSCS6) and $55 \%$ (pSCS7) of the original activity. However, CAT activity was significantly reduced by the presence of mercuric ions (Fig. 4). While $\mathrm{HgCl}_{2}$ concentrations of $0 \cdot 1$ and $0.3 \mathrm{~mm}$ had no influence on the activity of the pSCS6-encoded CAT, the activity of the CAT from
pSCS7 decreased to 15 and $10 \%$, respectively, of the original activity under the same conditions. At $1.0 \mathrm{~mm}$ $\mathrm{HgCl}_{2}$, the CAT from pSCS6 retained $50 \%$ of its original activity while no enzyme activity could be detected for the CAT from pSCS7.

\section{Discussion}

Nucleotide sequences of seven staphylococcal cat genes, carried by the plasmids pC221 (Brenner \& Shaw, 1985; Projan et al., 1985), pC194 (Horinouchi \& Weisblum, 1982), pUB112 (Brückner \& Matzura, 1985), pSCS1 (Schwarz et al., 1991), pSCS5 (Schwarz \& Cardoso, $1991 a$ ), pSCS6 (Cardoso \& Schwarz, 1992b) and pSCS7 (Schwarz \& Cardoso, 1991b), have been used for phylogenetic or comparative studies. Six staphylococcal 


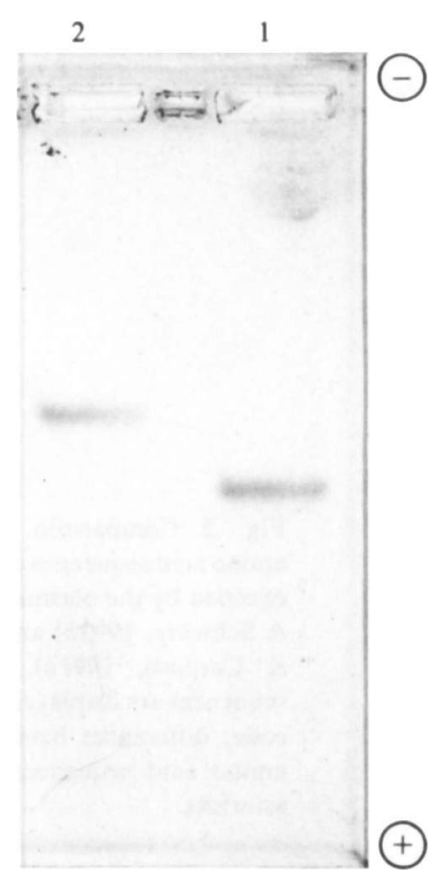

Fig. 3. Agarose gel electrophoresis of the native CAT variants from pSCS6 (lane 1) and pSCS7 (lane 2).

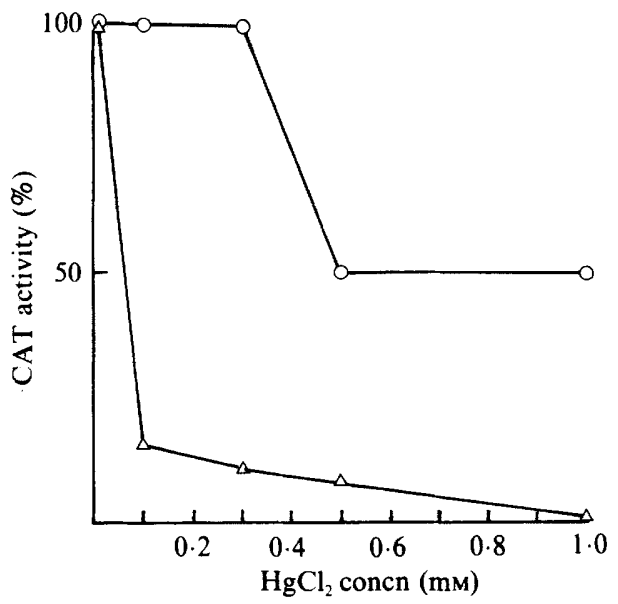

Fig. 4. Influence of mercuric ions on CAT activity. $O$, Activity of the pSCS6-encoded CAT; $\triangle$, activity of the pSCS7-encoded CAT. CAT activity is expressed as a percentage of the activity of the untreated control.

CAT enzyme variants have been distinguished. Four were designated A, B, C and D (Fitton \& Shaw, 1979). However, no genetic analysis has been conducted for the CAT variants A, B and D (Shaw, 1983). Although the CAT encoded by the $S$. aureus plasmid pC194 has not been isolated and characterized biochemically, it was considered to be a fifth staphylococcal CAT variant based on data predicted from its nucleotide sequence (Shaw, 1983). The CAT encoded by the $S$. haemolyticus plasmid pSCS5 represented the sixth staphylococcal CAT variant (Schwarz \& Cardoso, 1991a). Thus, comparative data on the deduced amino acid sequences and the biochemical properties of the CAT proteins are available only for the CAT C variant encoded by the $S$. aureus plasmid pC221 (Fitton \& Shaw, 1979; Brenner \& Shaw, 1985) and the pSCS5-encoded CAT variant from $S$. haemolyticus (Schwarz \& Cardoso, 1991a). The biochemical characteristics of the pSCS6- and pSCS7encoded CAT variants presented in this study provide an opportunity to correlate properties of those proteins with the deduced amino acid sequences.

The pSCS6-encoded CAT variant corresponded closely to the pC221-encoded CAT C on the basis of their predicted amino acid sequences (Cardoso \& Schwarz, $1992 b$ ). Only four amino acids of the pSCS6-encoded CAT monomer differed from the CAT $\mathrm{C}$ sequence. These amino acid exchanges occurred at positions which were not important for the structure and the function of the enzyme. The pSCS6- and pC221-specified CATs exhibited highest activities at pH 8.0; their $K_{\mathrm{m}}$ values for chloramphenicol were $2.5 \mu \mathrm{M}$ and their $K_{\mathrm{m}}$ values for acetyl-CoA varied only slightly, being $59 \mu \mathrm{M}$ for the CAT from pSCS6 and $61 \mu \mathrm{M}$ for the CAT from pC221. Moreover, both enzymes were thermostable and were relatively insensitive to mercuric ions (Fitton \& Shaw, 1979; Shaw, 1983; Shaw et al., 1970). Unfortunately, the isoelectric point of the pC221-encoded CAT variant is not known. The isoelectric point of the pSCS6-encoded CAT was determined here to be $\mathrm{pH} 5 \cdot 7$, differing substantially from the values for the CAT variants encoded by the plasmids pSCS5 (pH 6.15) (Schwarz \& Cardoso, 1991 a) and pSCS7 (pH 5.2).

The CAT variants from pSCS5 and pSCS7 were found to be related on the basis of their predicted amino acid sequences (Schwarz \& Cardoso, 1991b). However, the carboxy-terminal amino acid sequences differed completely. Nevertheless, these two CAT variants were assigned to the same evolutionary group, which is different from those represented by the pC221- and pC194-encoded CAT variants (Schwarz \& Cardoso, $1991 b$ ). The relationship between the CATs from pSCS5 and pSCS7 was also suggested by the observation that both CAT variants were very susceptible to mercuric ions. This property has also been described for the CAT B variant from S. epidermidis (Shaw et al., 1970). Moreover, the CAT from pSCS7 and CAT B corresponded closely in their $K_{\mathrm{m}}$ values. Both enzymes exhibited $K_{\mathrm{m}}$ values for chloramphenicol of $2.7 \mu \mathrm{M}$ and for acetyl-CoA of approximately $56 \mu \mathrm{M}$. The other $\mathrm{HgCl}_{2}$-sensitive CAT variant, from $\mathrm{pSCS} 5$, differed only slightly in its $K_{\mathrm{m}}$ values from these two CAT variants. The CAT from pSCS7 and CAT B also demonstrated highest activity at $\mathrm{pH} 8.0$, while the $\mathrm{pH}$ optimum for 


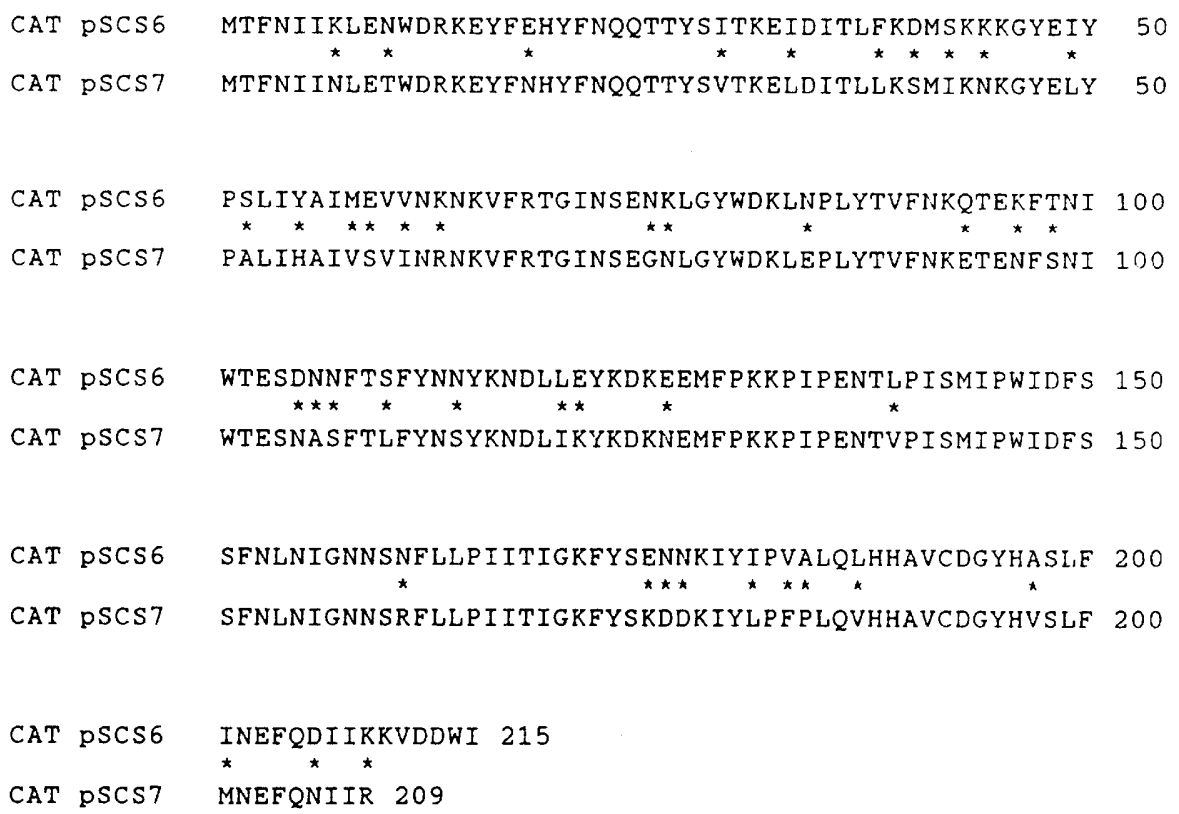

Fig. 5. Comparison of the predicted amino acid sequences of the CAT variants encoded by the plasmids pSCS6 (Cardoso \& Schwarz, 1992b) and pSCS7 (Schwarz \& Cardoso, 1991b). The amino acid sequences are displayed in the single-letter code; differences between the two CAT amino acid sequences are indicated by asterisks.
CAT from pSCS5 was slightly lower, at pH 7.8 (Schwarz \& Cardoso, 1991 a). The previously reported staphylococcal CAT variants B, C and D as well as the CAT variants encoded by the plasmids pSCS5, pSCS6 and pSCS7 were thermostable. Only CAT variant A was found to be thermolabile (Shaw, 1975).

All staphylococcal CAT variants exhibited the same quaternary structure. The $M_{\mathrm{r}}$ value of the pSCS6- and pSCS7-encoded CAT monomers was determined by SDS-PAGE to be 23000 , a result in good accordance with the $M_{\mathrm{r}}$ values calculated from the predicted pSCS6and pSCS7-encoded CAT amino acid sequences. Moreover, these $M_{\mathrm{r}}$ values corresponded very well to the value of 22500 , previously published for the monomers of the staphylococcal CAT variants A, B, C and D (Zaidenzaig et al., 1979), and that of 23000 , determined for the pSCS5-encoded CAT monomer (Schwarz \& Cardoso, $1991 a$ ). The experimentally determined $M_{\mathrm{r}}$ values of 70000 for the native CAT variants from pSCS6 and pSCS7 suggested that they exist as trimers composed of three identical subunits. A trimeric structure has previously been shown by X-ray crystallography of the R-factor-encoded type III CAT from Escherichia coli (Leslie et al., 1988).

The data presented in this study demonstrate that despite the differences in their primary structure, the CAT variants encoded by the plasmids pSCS6 and pSCS7 share several properties, namely a trimeric quaternary structure, similar $M_{\mathrm{r}}$ values of the CAT monomers, a common pH optimum and similar thermostability. These two CAT enzymes varied slightly in their kinetic parameters. However, as a consequence of the differences in their amino acid compositions they differed distinctly in their isoelectric points and their net charges. The active-site histidine at position 189 has previously been demonstrated to act as a general base catalyst in the acetylation of chloramphenicol (Leslie, 1990). This histidine residue was found to be conserved among all staphylococcal CAT variants so far investigated (Schwarz \& Cardoso, $1991 b$ ), including those from pSCS6 and pSCS7 (Fig. 5). The high affinity of mercuric ions for histidine might explain the general sensitivity of these enzymes to mercuric ions. The enhanced sensitivity of CAT B and the CAT variants encoded by pSCS5 and pSCS7 to mercuric ions could be due to differences in the accessibility and reactivity of His-189 in these CAT variants.

The authors wish to thank Mrs Sabine Grölz-Krug and Mrs Ute Neuschulz for excellent assistance.

\section{References}

Baumgartner, A., Nicolet, J. \& Eggiman, M. (1984). Plasmid profiles of Staphylococcus aureus causing bovine mastitis. Journal of Applied Bacteriology 56, 159-163.

BLOBEL, H. \& BRÜCKLER, J. (1980). Staphylokokken. In Handbuch der bakteriellen Infektionen bei Tieren, Band II, 1. Auflage, pp. 51-54. Edited by H. Blobel \& T. Schließer. Stuttgart \& New York: Gustav Fischer.

BRENNER, D. G. \& SHAw, W. V. (1985). The use of synthetic oligonucleotides with the universal templates for rapid DNA sequencing: results with staphylococcal replicon pC221. EMBO Journal 4, 561-568.

BRÜCKNER, R. \& MATZURA, H. (1985). Regulation of the inducible chloramphenicol acetyltransferase gene of the Staphylococcus aureus plasmid pUB112. EMBO Journal 4, 2295-2300. 
Cardoso, M. \& Schwarz, S. (1992a). Chloramphenicol resistance plasmids in Staphylococcus aureus isolated from bovine subclinical mastitis. Veterinary Microbiology (in the Press).

Cardoso, M. \& Schwarz, S. (1992b). Nucleotide sequence and structural relationships of a chloramphenicol acetyltransferase encoded by the plasmid pSCS6 from Staphylococcus aureus. Journal of Applied Bacteriology. (in the Press).

FitTon, J. E. \& SHAw, W. V. (1979). Comparison of chloramphenicol acetyltransferase variants in staphylococci. Biochemical Journal 177, 575-582.

GillesPie, M. T. \& SkURRaY, R. A. (1988). Structural relationships among chloramphenicol-resistance plasmids of Staphylococcus aureus. FEMS Microbiology Letters 51, 205-210.

HorinouChI, S. \& WeISBlum, B. (1982). Nucleotide sequence and functional map of $\mathrm{pC194}$, a plasmid that specifies inducible chloramphenicol resistance. Journal of Bacteriology 150, 815-825.

KreisWirth, B. N., LofDahl, S., Betley, M. J., O’Reilly, M., SChlievert, P. M., Bergdoll, M. S. \& Novick, R. P. (1983). The toxic shock syndrome exotoxin structural gene is not detectably transmitted by a prophage. Nature, London 305, 680-685.

LACEY, R. W. (1975). Antibiotic resistance plasmids of Staphylococcus aureus and their clinical importance. Bacteriological Reviews 39, $1-32$.

LAEMMLI, W. K. (1970). Cleavage of structural proteins during the assembly of the head of bacteriophage $\mathrm{T}_{4}$. Nature, London 227 , 680-685.

LESLIE, A. G. W. (1990). Refined crystal structure of type III chloramphenicol acetyltransferase at $1.75 \AA$ resolution. Journal of Molecular Biology 213, 167-186.

Leslie, A. G. W., Moody, P. C. E. \& SHAW, W. V. (1988). Structure of chloramphenicol acetyltransferase at $1.75 \AA$ resolution. Proceedings of the National Academy of Sciences of the United States of America 85, 4133-4137.

LiNEwEAVER, H. \& BURK, D. (1934). The determination of enzyme dissociation constants. Journal of the American Chemical Society 56, 658-666.

LYON, B. R. \& SKURRAY, R. (1987). Antimicrobial resistance of Staphylococcus aureus. Genetic basis. Microbiological Reviews 51, 88-134.

Maniatis, T., Fritsch, E. F. \& Sambrook, J. (1982). Molecular
Cloning: a Laboratory Manual. Cold Spring Harbor, NY: Cold Spring Harbor Laboratory.

Projan, S. J., Kornblum, J., Mogazeh, S. L., Edelman, I., Gennaro, M. L. \& Novick, R. P. (1985). Comparative sequence and functional analysis of pT181 and pC221, cognate plasmid replicons from Staphylococcus aureus. Molecular and General Genetics 199, 452-464.

ShaEG, W., BingöL, R. \& Blobel, H. (1972). Purification of penicillinase ( $\beta$-lactamase) and acid phosphatase from Staphylococcus aureus in one procedure. Biochimica et Biophysica Acta 268, $542-549$.

Schwarz, S. \& Cardoso, M. (1991 a). Molecular cloning, purification and properties of a plasmid-encoded chloramphenicol acetyltransferase from Staphylococcus haemolyticus. Antimicrobial Agents and Chemotherapy 35, 1277-1283.

Schwarz, S. \& Cardoso, M. (1991 b). Nucleotide sequence and phylogeny of a chloramphenicol acetyltransferase encoded by the plasmid pSCS7 from Staphylococcus aureus. Antimicrobial Agents and Chemotherapy 35, 1551-1556.

Schwarz, S., Cardoso, M. \& Blobel, H. (1989). Plasmid-mediated chloramphenicol resistance in Staphylococcus hyicus. Journal of General Microbiology 135, 3329-3336.

SchwarZ, S., SpIEs, U. \& CARDoso, M. (1991). Cloning and sequence analysis of a plasmid-encoded chloramphenicol acetyltransferase gene from Staphylococcus intermedius. Journal of General Microbiology 137, 977-981.

SHAw, W. V. (1975). Chloramphenicol acetyltransferase from chloramphenicol-resistant bacteria. Methods in Enzymology 43, 737-755.

SHAW, W. V. (1983). Chloramphenicol acetyltransferase: enzymology and molecular biology. CRC Critical Reviews in Biochemistry 14, $1-46$.

Shaw, W. V., Bentley, D. W. \& Sands, L. (1970). Mechanism of chloramphenicol resistance in Staphylococcus epidermidis. Journal of Bacteriology 104, 1095-1103.

Winshell, E. \& SHAW, W. V. (1969). Kinetics of induction and purification of chloramphenicol acetyltransferase from chloramphenicol-resistant Staphylococcus aureus. Journal of Bacteriology 98, 1248-1257.

Zaidenzaig, Y., Fitton, J. E., Packman, L. C. \& Shaw, W. V. (1979). Characterization and comparison of chloramphenicol acetyltransferase variants. European Journal of Biochemistry 100, 609-618. 